\title{
Habitus Masyarakat Lokal Desa Temajuk dalam Mengadaptasi Perkembangan Pariwisata
}

\author{
Aan Khosihan ${ }^{1}$ \\ Universitas Pendidikan Indonesia
}

\begin{abstract}
The development of tourism has many impacts on society including the habitus of local communities. In simple terms, it can be understood that the habitus is a system of habits that has been internalized in people's lives. This study aims to see the community's habitus in the midst of tourism development in Temajuk Village, Paloh District, Sambas Regency. This research is a qualitative study using primary interview data collection methods, Researchers interviewed local people who are involved in tourism both as active and passive actors. Through the habitus concept of Pierre Bourdieu, it can be conluded that a community of Temajuk village that intersects with the development of tourism which can be seen from the knowledge aspect where the community knows about the potential of tourist attractions, the understanding where the community understands that currently the village is a popular area for visiting and also the understanding of nature, the perception where there are two perceptions about understanding coastal area management, from the values, there are two values that can be highlighted which is solidarity and independence, form the action step, it is internalized in people's daily lives in the form of behavior called "jerampah", critical of development and taking part as active actors of tourism.
\end{abstract}

Keywords: Habitus, Adaptation of Local Communities, Development of Tourism

\begin{abstract}
Abstrak
Perkembangan pariwisata menghadirkan banyak dampak bagi masyarakat, termasuk habitus masyarakat lokal. Secara sederhana dapat dipahami bahwa habitus merupakan sistem kebiasaan yang telah terinternalisasi dalam kehidupan masyarakat. Penelitian ini bertujuan untuk melihat habitus masyarakat ditengah perkembangan pariwisata di Desa Temajuk, Kecamatan Paloh, Kabupaten Sambas. Penelitian ini merupakan penelitian kualitatif dengan metode pengumpulan data primer wawancara, peneliti mewawancari masyarakat lokal yang terlibat dalam kepariwisataan baik sebagai pelaku aktif maupun pelaku pasif. Melalui konsep habitus dari Pierre Bourdieu, dapat disimpulkan bahwa terdapat habitus masyarakat Desa Temajuk yang beririsan dengan perkembangan pariwisata yang dapat dilihat dari aspek pengetahuan dimana masyarakat mengetahui tentang potensi daya tarik wisata, pemahaman dimana masyarakat memahami bahwa saat ini desa mereka sedang menjadi daerah populer kunjungan wisata dengan pemahaman kelestarian alam, persepsi dimana terdapat dua persepsi tentang pemahaman pengelolaan kawasan pesisir, nilai dimana terdapat dua
\end{abstract}

\footnotetext{
1 aankhosihan@upi.edu
} 
nilai yang menonjol yaitu solidaritas dan kemandirian, serta tindakan yang terinternalisasi dalam kehidupan sehari-hari masyarakat berupa perilaku jerampah, kritis mengenai arah pengembangan wisata dan mengambil bagian sebagai pelaku aktif pariwisata.

Kata Kunci : Habitus, Adaptasi Masyarakat Lokal, Perkembangan Pariwisata

\section{Pendahuluan}

Perkembangan pariwisata di Desa Temajuk tidak terlepas dari meningkatnya jumlah kunjungan tahunan penduduk, sayangnya hingga saat ini pemerintah Desa Temajuk tidak membuat catatan tahunan mengenai jumlah wisatawan yang berkunjung ke Desa Temajuk. Sebagai desa yang baru berkembang, saat ini Desa Temajuk masih mengandalkan potensi alamnya berupa pantai dan laut sebagai objek daya tariknya. Di sisi lain, potensi hutan juga sangat menjanjikan. Lahan hutan yang ada mencapai luas kurang lebih 1.550 ha, saat ini menghasilkan madu lebah cukup memadai (Ihsayani \& Handono, 2017). Selain itu, beberapa kebiasaan masyarakat yang tingggal di daerah pesisir cukup unik, sehingga berpeluang untuk menjadi potensi pengembangan pariwisata dengan proses komodifikasi budaya (Pookhao, et al, 2018).

Sejarah Desa Temajuk yang bukan merupakan daerah tujuan wisata seperti saat ini, menjadi latar belakang yang menarik untuk dilihat, dimana penelitian mengenai proses pembentukan habitus masyarakat Desa Temajuk mengenai pariwisata masih belum ditemukan. Habitus memegang peran penting dalam konsep praktik sosial, habitus memberikan prinsip yang digunakan orang dalam memilih strategi yang akan mereka gunakan di dunia sosial (Ariyani, dkk, 2017). Disisi lain, bentuk-bentuk perubahan habitus masyarakat yang teraktualisasi dalam bentuk tindakan dapat menjadi pengalaman budaya bagi para wisatawan, sehingga berpotensi bagi pemangku kebijakan untuk melirik aspek ini (Cetin \& Bilgihan, 2016).

Selama periode 2016 hingga saat ini, keterlibatan stake holder pengembangan pariwisata mulai terlihat. Hal ini tampak pada pemerintah dan 
pihak swasta yang telah ikut ambil bagian dalam upaya pengembangan pariwisata di Desa Temajuk, pemerintah melakukan kegiatan pengawasan dan pembinaan dalam rangka mendukung perkembangan pariwisata di Desa Temajuk (Meriyanti, dkk, TT). Data dari dinas pariwisata, pemuda dan olahraga kabupaten sambas, pada tahun 2019 tercatat Desa Temajuk telah memiliki 27 homestay dan 20 penginapan dengan total sekiar 226 kamar (Khosihan, 2019).

Adanya bentuk-bentuk perubahan yang terjadi di Desa Temajuk mulai dari yang awalnya bukan daerah tujuan wisata hingga saat ini menjadi daerah objek tujuan wisata, membuat peneliti ingin melihat bagaimana habitus masyarakat Desa Temajuk dalam memandang perkembangan pariwisata. Sehubungan dengan hal ini, peneliti menggunakan lima aspek habitus yaitu pengetahuan, pemahaman, persepsi, nilai, dan tindakan yang terinternalisasi dalam kehidupan sehari-hari (Kusmartanti, 2017: 130). Sebagai kegiatan wisata yang didukung oleh berbagai fasilitas serta layanan yang disediakan oleh masyarakat, pengusaha, pemerintah, dan pemerintah daerah (UU No. 10 tahun 2009). Perkembangan pariwisata dalam praktiknya akan menimbulkan berbagai dampak baik positif maupun negatif berkaitan dengan ekonomi, sosial, maupun lingkungan, termasuk habitus masyarakat.

Habitus diartikan sebagai bentuk badan; perawakan (KBBI). Konsep habitus menawarkan alternatif solusi yang ditawarkan subjektivisme, (Demartoto, dkk. 2013:28). Sebagai sebuah sistem disposisi yang bertahan lama dan bisa dialihpindahkan (transposable), habitus merupakan struktur yang distrukturkan yang diasumsikan berfungsi sebagai penstruktur strukturstruktur (structured structures predisposed to function as structuring structure), yaitu sebagai prinsip-prinsip yang melahirkan dan mengorganisasikan praktik-praktik dan representasi-representasi yang bisa diadaptasikan secara objektif kepada hasil-hasilnya tanpa mengandaikan suatu upaya sadar mencapai tujuan-tujuan tertentu atau penguasaan cepat atas cara 
dan operasi yang diperlukan untuk mencapainya", (Demartoto, 2014:28). Hal ini mengandung bahwa praktik-praktik atau representasi yang dilihat dapat dianalisis dengan cara-cara tertentu. Habitus dalam teori sosiologi dimaksudkan sebagai struktur mental kognitif yang menghubungkan manusia dengan dunia sosial. Manusia dianggap dibekali dengan serangkaian skema terinternalisasi yang digunakan untuk melahirkan persepsi, pemahaman, apresiasi, dan evaluasi atau kemampuan menilai terhadap dunia sosial". (Ritzer \& Douglas, 2009: 581),

Dalam pandangan Bourdieau, habitus dapat diidentifikasi melalui pengetahuan, pemahaman, persepsi, nilai, dan tindakan yang terinternalisasi dalam kehidupan sehari-hari (Kusmartanti, 2017: 130. Habitus diartikan sebagai seperangkat pengetahuan, kepercayaan, dan nilai dalam kehidupan. setidaknya, tiga komponen yang ada pada konsep habitus akan sangat membantu strategi pengembangan wisata, karena ketiga unsur tersebut merupakan aspek yang sangat penting sebagai karakter masyarakat lokal di lokasi wisata. Habitus merupakan struktur mental yang digunakan individu atau kelompok untuk menghadapi kehidupan sosial, artinya, selain dimensi objektif dari sebuah habitus, terdapat pula unsur subjektif yang terdapat dalam alam pikir individu ataupun masyarakat. Proses habituasi berlangsung dalam jangka waktu yang panjang pada tempat dimana seorang individu ataupun kelompok tinggal. Bourdieu berpandangan bahwa habitus terbentuk dari interaksi dengan orang lain (Demartoto, dkk, 2014: 45),

Habitus masyarakat lokasi wisata memegang peran penting dalam pengembangan pariwisata, hal ini mengingat bahwa perilaku masyarakat yang akan berinteraksi dengan wisatawan akan sangat berpengaruh bagi keberlangsungan pariwisata itu sendiri. Pengembangan pariwisata tidak boleh meminggirkan budaya dan spirit lokal (Sutarso, 2012). Habitus yang ada dalam masyarakat dapat menjadi rujukan terkait kepercayaan, nilai dan pengetahuan masyarakat lokal anut untuk selanjutnya bisa menjadi bekal 
dalam upaya mensosialisasikan konsep-konsep kepariwisataan ideal bagi masyarakat disuatu lokasi wisata. Dapat dikatakan, bahwa habitus masyarakat tidak hanya dapat menjadi daya tarik kepariwisataan, namun juga mengambil peran penting bagi perkembangan pariwisata.

\section{Metode Penelitian}

Penelitian ini menggunakan pendekatan penelitian kualitatif, dengan model penyajian yang menghasilkan data deskriptif berupa kata-kata tertulis dari orang-orang dan perilaku yang dapat diamati (Moleong, 2014). Sumber data utama dalam penelitian ini adalah informasi yang diperoleh dari para pelaku pariwisata di Desa Temajuk yaitu masyarakat lokal yang terlibat dalam aktivitas kepariwisataan baik sebagai pelaku pasif maupun pelaku aktif di Desa Temajuk, Kecamatan Paloh, Kabupaten Sambas. Adapun sumber data lainnya bersifat sekunder seperti foto-foto kegiatan yang berhubungan dengan kepariwisataan di Desa Temajuk, kemudian dokumen-dokumen berupa data desa dan isian potensi desa, hingga berita-berita dari media nasional maupun lokal. Peneliti mengumpulkan data primer dengan wawancara secara mendalam kepada informan. Proses pengolahan data dilakukan dengan Triangulasi sampai akhirnya disimpulkan ketika dinyatakan valid dan reliabel.

\section{Hasil dan Pembahasan}

Habitus Masyarakat Desa Temajuk dapat dilihat dari berbagai aspek, sederhananya, habitus merupakan kebiasaan. Dalam pandangan Bourdieau, habitus dapat diidentifikasi melalui pengetahuan, pemahaman, persepsi, nilai, dan tindakan yang terinternalisasi dalam kehidupan sehari-hari (Kusmartanti, 2017: 130). Tidak semua praktik yang ada dalam pengembangan pariwisata Desa Temajuk berhubungan dengan habitus, namun ada beberapa praktik yang jelas merupakan bagian dari habitus masyarakat. Contoh nyata praktik pengembangan pariwisata Desa Temajuk yang mengandung unsur habitus 
masyarakat adalah pada pergelaran festival pesisir Paloh sebagaimana jawaban infoman DP berikut.

"Dulu, masyarakat Paloh (termasuk Temajuk) terbiasa mengonsumsi telur penyu, sampai terdapat kebiasaan untuk merayakannya banyaknya telur penyu ini dengan festival lempar telur penyu, kebiasaan ini mulai berubah seiring sosialisasi oleh pmerintah dan komunitas pecinta lingkungan untuk menjaga kelestarian penyu dengan tidak mengonsumsi, dan memperjualbelikannya ke pasar". (wawancara tanggal 11 Maret 2019).

Kegiatan ini berangkat dari kebiasaan masyarakat untuk memburu telur penyu untuk dikonsumsi dan dijual. Saat itu, pengetahuan akan khasiat telur penyu yang dapat menambah stamina membuatnya ramai diburu. Pemahaman masyarakat yang dahulu memburu telur penyu sebagai produk ekonomi, kemudian mulai berubah ketika masuk sosialiasasi dari pemerintah dan organisasi pegiat lingkungan WWF mengenai kelestarian penyu. Pelan dan pasti, pada akhirnya habitus masyarakat berubah dari pemburu telur penyu menjadi pelestari telur penyu dan pendamping bagi wisatawan yang ingin melihat sarang penyu maupun proses penyu bertelur. Melalui festival pesisir Paloh, yang dulu dinamakan festival lempar telur penyu sebagai wujud rasa syukur atas melimpahnya telur penyu kini masyarakat dan wisatawan diajak untuk melepas tukik dan diedukasi bahwa keberadaan tukik yang dilepas dalam jumlah ratusan, akan tumbuh menjadi penyu dewasa dalam jumlah satu atau dua saja karena proses seleksi alam. Hal ini merupakan wujud nyata dari habitus sebagai pembekalan serangkaian pola atau yang diinternalisasi yang mereka gunakan untuk merasakan, memahami, dan menyadari dan menilai dunia sosial (Ritzer, 2011). Festival pesisir Paloh adalah gambaran nyata bahwa habitus bisa berubah dalam pola yang terstruktur, karena sangat erat kaitannya dengan struktur mental dan kognitif. Pada konteks ini pula, aspek habitus masyarakat yang mulai berubah merupakan cerminan dari pengelolaan pariwisata yang tidak meminggirkan budaya dan spirit lokal (Sutarso, 2012). 
Dalam praktik kehidupan sehari-hari masyarakat, posisi habitus yang dianggap sebagai struktur mental kognitif yang menghubungkan manusia dengan dunia sosial (Ritze dan Douglas (2009:581) membuat kondisi masyarakat Desa Temajuk memiliki ciri khas dalam praktik kehidupannya. Peneliti juga menemukan beberapa habitus yang berhubungan dengan Desa Temajuk, seperti kepercayaan masyarakat bahwa Desa Temajuk yang merupakan bagian dari daerah kebanarran, dimana kita tidak bisa berkata yang mendahului takdir. Dikalangan nelayan, pantang untuk menyebutkan sesuatu yang belum terjadi. Misalnya ketika akan melaut, nelayan tidak boleh menyebutkan akan mencari ikan untuk "bekal lauk dirumah saja", hal ini akan membuat hasil tangkapan menjadi seperti yang disebutkan. Untuk itu, nelayan di Desa Temajuk sudah faham betul bagaimana menjaga lisan terutama yang berhubungan dengan sesuatu yang belum terjadi. Selanjutnya, pada musim ubur-ubur, peneliti menemukan bahwa habitus masyarakat ketika melaut pada musim ubur-ubur hanya terjadi pada siang hari, tidak ada yang memburu ubur-ubur pada malam hari, hal ini dikarenakan kepercayaan masyarakat bahwa apabila ubur-ubur dicari pada malam hari akan membuat ubur-ubur itu akan menghilang pada tahun berikutnya, dan ini sudah dipraktikkan oleh masyarakat Desa Temajuk selama bertahun-tahun.

Habitus masyarakat Desa Temajuk tentang pengembangan pariwisata berkaitan erat dengan pengetahuan masyarakat bahwa mereka memiliki pemandangan pantai yang indah dengan tingkat kejernihan air laut yang lebih baik dibanding dengan pantai-pantai lainnya di Kabupaten Sambas. Hal ini sebagaimana pernyataan informan Ar.

"Seperti yang saya katakan sebelumnya secara alam, kita memang memiliki pantai yang indah, pemandangan laut pada siang ataupun saat matahari tenggelam yang memang tidak perlu kita ragukan lagi pesonanya" (wawancara tanggal 9 februari 2019) 
Potensi pantai yang mereka ketahui ini karena semua orangtua yang tinggal di Desa Temajuk berasal dari luar Temajuk, sehingga mereka tahu bagaimana perbandingan kondisi pantai yang ada di Desa Temajuk dengan pantai-pantai lainnya di Kabupaten Sambas. Mereka juga mengetahui bahwa Desa Temajuk merupakan wilayah terluar indonesia, hal ini menggambarkan bahwa habitus masyarakat Desa Temajuk dibentuk dalam moment praktik, dalam arti habitus dilakukan oleh agen bersangkutan dalam menemui masalah kehidupan sehari-hari (Mutahir, 2011). Masalah yang dimaksud adalah ketika masyarakat ditanya mengenai apa yang membuat daerah mereka berbeda dengan daerah lainnya, maka kognisi masyarakat akan menjawab pada perbandingan kondisi alam mereka dengan daerah lainnya di Kabupaten Sambas.

Berkaitan dengan pemahaman, masyarakat Desa Temajuk memahami bahwa sebagai wilayah yang potensial dengan panorama pantainya yang indah maka saat ini Desa mereka mulai menjadi primadona. Hal ini terkait dengan jumlah kunjungan wisatawan yang terus membludak tiap tahunnya terutama pada musim libur lebaran. Sebenarnya, keberadaan hutan lindung hingga batas wilayah negara sudah diketahui oleh masyarakat, hanya saja dalam praktiknya belum terlalu dipahami. Setelah menjadi perhatian negara karena kasus pergeseran patok batas, maka masyarakat sering mendapat edukasi tidak hanya mengenai patok batas, tapi juga pemahaman akan pemanfaatan hutan lindung, pengelolaan wilayah pantai, dan melaporkan temuan-temuan terkait isu kedaulatan.

Dari sisi persepsi, pasca masyarakat mengetahui bahwa Temajuk khususnya Tanjung Datuk merupakan kawasan hutan lindung dan terdapat aturan dalam pengelolaan kawasan pesisir melalui UU No. 41 tahun 1999 (yang ditempel pada papan informasi Desa) dan diedarkan sejak april 2016. Persepsi masyarakat bagi pengembangan pariwisata Desa Temajuk terbagi menjadi beberapa poin, pertama masyarakat menganggap bahwa kawasan 
pantai yang mereka huni saat ini adalah milik mereka sendiri sesuai dengan surat tanah yang mereka miliki sehingga masih berhak untuk mengeksploitasi lahan mereka sendiri namun bibir pantainya saja yang bukan. Pada praktiknya memang terlihat banyak penginapan yang dibangun nyaris mendekati bibir pantai, hal itu disebabkan oleh persepsi masyarakat yang merasa lahan yang mereka huni adalah bagian dari hak mereka untuk mengelolanya begitupun dengan kawasan hutan lindung. Dalam rangka mencari bahan kebutuhan pembangunan penginapan maupun rumah, masyarakat sudah tidak bisa leluasa lagi menebang pohon. Namun mereka menyadari bahwa kedekatan mereka dengan alam seperti masa lalu tidak bisa lagi dilakukan secara bebas seperti pada saat ini. Maka dapat disimpulkan bahwa persepsi masyarakat Desa Temajuk berkaitan dengan pengembangan wisata terbagi menjadi dua yaitu masyarakat yang menganggap bahwa kawasan hutan dan pantai merupakan hak mereka untuk mengelolanya pada wilayah mereka tinggal. dan masyarakat yang menganggap kawasan pantai dan hutan pengelolaannya harus mengikuti aturan.

Pada nilai yang dianut masyarakat, habitus dapat pula diidentifikasikan dengan nilai yang diyakini oleh masyarakat setempat (Kusmartanti, 2017:135). Bourdieu menganggap bahwa habitus dapat dilihat dari nilai-nilai yang dihayati manusia yang tercipta melalui proses sosialisasi yang berlangsung lama dan menjadi cara berpikir dan pola perilaku yang menetap pada diri manusia. Dari hasil penelitian, nilai yang dimiliki masyarakat Desa Temajuk dalam upaya pengembangan pariwisata bekaitan dengan solidaritas untuk menjadikan wisata Desa Temajuk menjadi lebih baik yaitu dengan kemauan masyarakat untuk ikut gotong royong dan saling membantu dalam memecahkan masalah bersama, termasuk dalam menepati aturan-aturan bersama, hal ini sebagaimana diungkapkan oleh informan Jo. 
“..,Misal dalam upaya pelebaran jalan, masyarakat bekerjasama dengan investor untuk melebarkan dan meratakan tanah di dusun maludin supaya jalan menuju objek batu nenek bisa dimasuki oleh mobil" (wawancara tanggal 14 februari 2019)

Nilai selanjutnya yang tampak adalah kemandirian, masyarakat Desa Temajuk dikenal sebagai masyarakat yang mandiri, sejak dahulu mereka datang ke Temajuk tanpa fasilitas apapun, Temajuk awalnya adalah hutan belantara dan pesisir. Hal ini tergambar dari jawaban informan Po dengan pernyataan berikut.

"Saat ini listrik hanya menyala dari jam 4 sore hingga pukul 6 pagi. Tapi kita beharap sekali bisa 24 jam, hal ini mungkin masih lama listrik saja baru masuk sekitar dua tahun, dari situ kita sudah merasa merdeka, apalagi jika 24 jam mengalir" wawancara tanggal 8 februari 2019

Ketika listrik saja baru masuk dua tahun lalu, sebelumnya masyarakat sudah menggunakan genset. Ketika jalan belum tehubung, masyarakat menggunakan jalur pantai untuk bepergian. Hal ini dirasakan begitu jelas pada saat penelitian, seperti saat ini dimana belum maksimalnya layanan komunikasi internet, masyarakat menggunakan provider luar negeri. Kemandirian ini berasal dari keterbatasan, keterbatasan melahirkan inisiatif masyarakat perbatasan yang belum tentu mudah diterima oleh masyarakat yang dekat dengan pusat ibukota.

Dari segi tindakan, habitus masyarakat Desa Temajuk yang berhubungan dengan pengembangan pariwisata tewujud dalam aktualisasi pengetahuan, pemahaman dan persepsi. Masyarakat yang menyadari bahwa daerah mereka mulai ramai dikunjungi saat ini memiliki kepekaan dalam menyambut tamu. Perilaku jerampah menjadi tindakan nyata masyarakat dalam menyambut tamu. Sebagaimana pernyataan informan Po. 
"Masyarakat kita dikenal dengan istilah jerampah, yaitu sifat yang menjadi ciri khas orang melayu Sambas ketika bertemu dengan orang lain. Hal ini mencakup bagaimana cara bertutur sapa, memperlakukan tamu, menyediakan makanan dan sebagainya". (wawancara Tanggal 8 Februari 2019)

Kemudian, saat ini masyarakat lebih cenderung kritis dalam upaya pengembangan pariwisata, hal ini terlihat pada kekhawatiran beberapa tokoh masyarakat mengenai arah pengembangan pariwisata, supaya jangan sampai budaya Melayu dan Islam menjadi hilang di Desa Temajuk. Masyarakat Desa Temajuk cenderung berpakaian sopan dalam penampilannya sehari-hari, ini merupakan wujud dari nilai-nilai Melayu dan Islam yang mendominasi kehidupan masyarakat Desa Temajuk. Tindakan berikutnya yang jelas terlihat adalah berusaha untuk mengikuti perkembangan kepariwisataan di desa, masyarakat tidak hanya pasif dan melihat pembangunan penginapan yang dilakukan oleh pihak swasta maupun pengusaha, namun juga mereka mulai membuka diri dalam pendataan homestay termasuk menyediakan kamar untuk menginap dan mengikuti sosialisasi gerakan sadar wisata.

Secara khusus, habitus masyarakat dalam pengembangan pariwisata di Desa Temajuk dapat dilihat pada tabel berikut :

Tabel 1.1

Habitus Masyarakat Lokal Desa Temajuk dalam Mengadaptasi Perkembangan Pariwisata

\begin{tabular}{|l|l|l|}
\hline No & \multicolumn{1}{|c|}{$\begin{array}{c}\text { Karakterisitik } \\
\text { Habitus }\end{array}$} & \multicolumn{1}{c|}{ Identifikasi } \\
\hline 1 & Pengetahuan & $\begin{array}{l}\text { Pengetahuan bahwa Temajuk memiliki } \\
\text { tipikal pantai yang lebih indah } \\
\text { - Pengetahuan akan wilayah terluar Indone }\end{array}$ \\
\hline 2 & Pemahaman & $\begin{array}{l}\text { - Pemahaman bahwa Desa Temajuk sedang } \\
\text { menjadi primadona wisata di Kabupaten } \\
\text { Sambas } \\
\text { - Pemahaman akan pemanfaatan hutan } \\
\text { lindung dan pantai }\end{array}$ \\
\hline 3 & Persepsi & $\begin{array}{l}\text { Persepsi bahwa kawasan pantai yang } \\
\text { berada dipekarangan rumah adalah hak } \\
\text { kelola pribadi }\end{array}$ \\
\hline
\end{tabular}




\begin{tabular}{|c|c|c|}
\hline & & $\begin{array}{l}\text { - Persepsi bahwa pengelolaan kawasan } \\
\text { pantai dan hutan harus sesuai aturan }\end{array}$ \\
\hline 4 & Nilai & $\begin{array}{l}\text { - Solidaritas dalam menjalankan aturan- } \\
\text { aturan bersama } \\
\text { - Kemandirian masyarakat untuk tidak } \\
\text { sepenuhnya bergantung pada pemerintah }\end{array}$ \\
\hline 5 & Tindakan & 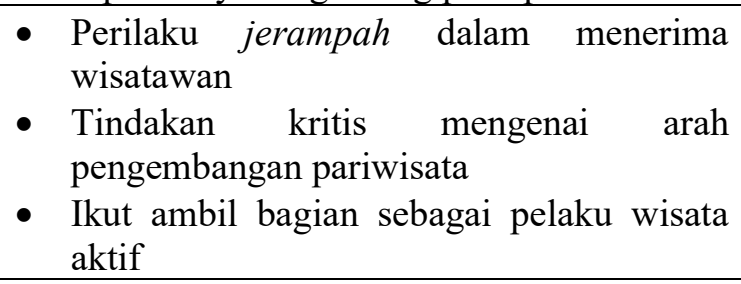 \\
\hline
\end{tabular}

\section{Kesimpulan}

Adanya perubahan-perubahan situasi dalam masyarakat di Desa Temajuk seiring dengan masifnya kunjungan wisatawan dan masuknya pihakpihak yang peduli dengan perkembangan pariwisata di desa temajuk membuat habitus masyarakat mengalami perubahan dalam memandang pariwisata. Hal ini teraktualisasi dalam tindakan masyarakat lokal yang ambil bagian dalam proses pengembangan pariwisata di Desa Temajuk. Namun, tindakan yang mencerminkan habitus ini telah melalui tahapan-tahapan mulai dari pengetahuan, pemahaman, persepsi, dan nilai-nilai yang mendukung pengembangan pariwisata di Desa Temajuk. Pada aspek pengetahuan dimana masyarakat mengetahui tentang potensi daya tarik wisata, pemahaman dimana masyarakat memahami bahwa saat ini desa mereka sedang menjadi daerah populer kunjungan wisata dengan pemahaman kelestarian hutan lindung, persepsi dimana terdapat dua persepsi tentang pemahaman pengelolaan kawasan pesisir, nilai dimana terdapat dua nilai yang menonjol yaitu solidaritas dan kemandirian, serta tindakan yang terinternalisasi dalam kehidupan sehari-hari masyarakat berupa perilaku jerampah, kritis mengenai arah pengembangan wisata dan mengambil bagian sebagai pelaku aktif pariwisata. 
Habitus Masyarakat Lokal Desa Temajuk dalam Mengadaptasi Perkembangan

Pariwisata

\section{Daftar Pustaka}

Ariyani, N. I., Demartoto, A., \& Zuber, A. (2018). Habitus Pengembangan Desa Wisata Kuwu: Studi Kasus Desa Wisata Kuwu Kecamatan Kradenan Kabupaten Grobogan. Jurnal Analisa Sosiologi, 4(2).

Cetin, G., \& Bilgihan, A. (2016). Components of cultural tourists' experiences in destinations. Current Issues in Tourism, 19(2), 137154.

Demartoto, Argyo. (2014). Habitus, Pengembangan Pariwisata, Konsep dan Aplikasi. Surakarta, UNS Press.

Demartoto, Argyo. Sugiarti, Rara. Utami, Trisni. Widiyanto. Adi, kunto, R. (2013) Pembangunan Pariwisata Berbasis Masyarakat. Surakarta, UNS Press.

Ihsaniyati, H., \& Handono, S. Y. (2017). Empowerment Civil Society untuk Mendukung Kebijakan dan Mimpi Desa Temajuk Sebagai Desa Wisata di Batas Negeri. Inoteks, 21(1), 1-13.

Kusmartanti, Dwiana. (2017). Praktik Sosial Pelestarian Situs Manusia Purba Sangiran Sebagai Cagar Budaya (Studi Kasus Pada Masyarakat Sekitar Situs Cagar Budaya Manusia Purba di Sangiran). Surakarta, Tesis UNS.

Meriyanti, M., Aminuyati, A., \& Herkulana, H. Pengaruh Pariwisata Temajuk dan Pemberdayaan Ekonomi Terhadap Kesejahteraan Masyarakat Sambas. Jurnal Pendidikan dan Pembelajaran Khatulistiwa, 8(10).

Mutahir, A., \& Muzir, I. R. (2011). Intelektual Kolektif Pierre Bourdieu: Sebuah Gerakan untuk Melawan Dominasi. Kreasi Wacana.

Pookhao Sonjai, N., Bushell, R., Hawkins, M., \& Staiff, R. (2018). Community-based ecotourism: beyond authenticity and the commodification of local people. Journal of Ecotourism, 17(3), 252267.

Ritzer dan Goodman. (2009). Teori Sosiologi : Dari Teori Klasik Sampai Perkembangan Mutakhir Teori Sosiologi Post Modern. Yogyakarta: Kreasi Wacana.

Sutarso, J. (2012). Menggagas Pariwisata Berbasis Budaya dan Kearifan Lokal. Prosiding Seminar Nasional "Menggagas Pencitraan Berbasis Kearifan Lokal" dalam rangka Dies Natalies Jurusan Ilmu Komunikasi Univ. Jend. Soedirman Ke-14 (pp. 505-515). 